\title{
Evidence against HLA and immunological dependence of disease outbreak in SLE. Immunological characterisation of identical twins clinically discordant for SLE
}

\author{
ESA SOPPI, JUSSI ESKOLA, AND AAPO LEHTONEN \\ From the Departments of Medicine and Medical Microbiology, University of Turku, SF-20520 Turku 52, \\ Finland
}

SUMmaRY Identical female twins clinically discordant for 20 years for SLE were studied. Their HLA-haplotype was A1,28; B8w6,w35; Cw3,w7; Dr3,4. Both twins had a raised erythrocyte sedimentation rate, autoantibodies, and circulating immune complexes. The diseased sibling had a reversed OKT4/OKT8 ratio $(0 \cdot 43)$, decreased helper $\mathrm{T}$ cell number, defective pokeweed mitogen (PWM) induced plasma cell differentiation, and overactive hydrocortisone sensitive suppressor cells. Immunological abnormalities may be only partly HLA related (B8; Dr3), but are most probably secondary to the disease process in the sibling with SLE. Exogenous and/or endogenous factor(s) other than genetic or immunological are suggested as being operative in the predisposition to and expression of SLE.

Key words: HLA dependence, immunology.

Although the aetiology of systemic lupus erythematosus (SLE) remains unknown, genetic factors have been implicated in SLE for several reasons. Its concordance in identical twins is high $(57-71 \%)^{1}$ and the disease has a tendency to occur among immediate relatives. ${ }^{2}$ SLE is characterised by a host of immune abnormalities. Patients often have decreased $\mathrm{T}$ cell function and deficiencies of normal suppressor mechanisms as well as endogenous polyclonal $\mathrm{B}$ cell activation. ${ }^{3-8}$ The evidence that immune responses in animals often are under control of histocompatibility antigens has prompted investigators to seek an association between SLE and HLA genetic markers. ${ }^{10}$ When association has been suggested, it has been linked to HLA A1,B5,B7,B8,DR2, and Dr3 antigens. ${ }^{910}$ Furthermore suppressor cell defect has been suggested to be a genetic marker for SLE susceptibility. ${ }^{4}$ It has been proposed that genetic factors predispose to autoimmunity via immunoregulatory circuits before autoantibody or clinical symptoms appear. ${ }^{3} 811$ In

Accepted for publication 7 June 1984.

Correspondence to Esa Soppi. MD. Department of Medicine. University of Turku, SF-20520 Turku 52. Finland. the present study extensive immunological analysis was carried out in identical twins discordant for SLE.

\section{Patients and methods}

PATIENTS AND CONTROLS

The salient clinical and laboratory features of the twins are shown in Table 1. A diagnosis of SLE in the diseased sibling satisfied the criteria adopted by the American Rheumatism Association. ${ }^{12}$ Monozygosity of the twins was confirmed by an analysis of HLA antigens and nine blood group antigens (AOB, Rh, Kell, Duffy, Kidd, Lewis, MNS, P. Lutheran). There were 11 female and 4 male control subjects, mean age 36 years, SD 8 years. None of the subjects used any medication.

The controls were included in the study to provide a normal range for the assays, not a formal case control comparison.

IMMUNOLOGICAL METHODS

Autoantibodies, serum immunoglobulins, HLA, and blood group antigens were determined by 
standard techniques. $T$ lymphocyte subsets were identified with monoclonal antibodies (OKT 3, 4 and 8 ) and $B$ cells by detecting immunoglobulin positive cells with direct immunofluorescence. ${ }^{13}$ For lymphocyte blastogenesis whole blood and isolated lymphocytes were stimulated with three concentrations of phytohaemagglutinin (PHA M) and concanavalin $\mathrm{A}$ (con A). ${ }^{14}$ All counts are corrected to the reference day of ${ }^{125} \mathrm{I}$-iododeoxyuridine. In addition, the effects of indomethacin (Ind), cimetidine (Cim), and D-penicillamine with copper sulphate $(\mathrm{Pen}+\mathrm{Cu})$ on lymphocyte transformation were recorded. ${ }^{15-17} \mathrm{~B}$ cell function was measured by a reverse plaque forming cell (PFC) assay. ${ }^{18}$ Spontaneous as well as pokeweed mitogen (PWM) induced PFC capacity and the effects of hydrocortisone and concanavalin $\mathrm{A}^{19}$ on the number of PFC induced by PWM were determined.

\section{Results}

The sibling with SLE (AS) had had symptoms for the last 20 years while her sister (BS) was symptom- less. The diseased twin differed from the healthy? one in respect of the positivity of anti-DNA antis bodies and raised serum $\operatorname{IgM}$ and $\operatorname{IgA}$ concentra tions. They were HLA identical (A1,28\% B8,w6,w35; Cw3,w7; Dr3,4) (Table 1). Tests fo모. complement components excluded inherited com: plement deficiencies.

The numbers of leucocytes, lymphocytes, and $\mathbb{P}^{2}$ Lymphocytes of the twins were within normal range $\overrightarrow{\dot{p}}$ The reversed OKT4/OKT8 ratio $(0 \cdot 43)$ in the SLE patient (AS) was due to the increased number oft suppressor/cytotoxic cells and decreased number of helper cells. The healthy sibling had a slightl\% decreased number of helper cells, resulting in ait OKT4/OKT8 ratio of $1 \cdot 16$ (Table 2).

PHA induced lymphocyte blastogenesis of this twins did not differ from that of the controls. The same was true of con A responses in whole blood cultures. When isolated lymphocytes were used, co $\vec{B}$ A responses of the twins were lower than those of the controls and the healthy twin had lower responses than the diseased one. The findings with all mitoge concentrations gave similar results. The data wit $\vec{b}$

Table 1 Clinical data of the twins

\begin{tabular}{|c|c|c|c|c|c|c|c|c|c|c|}
\hline \multirow{3}{*}{$\frac{T \text { win }}{\text { AS }}$} & \multirow{3}{*}{$\begin{array}{l}\text { Sex } \\
\mathrm{F}\end{array}$} & \multirow{3}{*}{$\frac{\text { Age }}{35}$} & \multicolumn{5}{|c|}{ Diagnosis and clinical features } & \multicolumn{3}{|c|}{ HLA haplotypes } \\
\hline & & & \multirow{3}{*}{\multicolumn{5}{|c|}{$\begin{array}{l}\text { Symptoms at the age of } 12 \text { years; butterfly rash, } \\
\text { severe arthralgia and arthritis, } 1976 \text { pleuritis, } \\
\text { and pulmonary infiltrations } \\
\text { Diagnosis: SLE } \\
\text { Clinically totally healthy, sedimentation rate } \\
40-100 \mathrm{~mm} / \mathrm{h} \text { since } 1971\end{array}$}} & A1,28; & \multicolumn{2}{|c|}{ B8,w6,w35; } \\
\hline & & & & & & & & Cw3,w7: & \multicolumn{2}{|c|}{ Dr3,4 } \\
\hline BS & $\mathbf{F}$ & 35 & & & & & & A1 28 & \multicolumn{2}{|c|}{ B8,w6,w35; } \\
\hline \multirow{3}{*}{ Twin } & \multirow{3}{*}{$\begin{array}{l}E S R \\
m m / h\end{array}$} & \multirow{3}{*}{$\begin{array}{l}\text { Waaler- } \\
\text { Rose }\end{array}$} & \multirow{2}{*}{\multicolumn{3}{|c|}{$\begin{array}{l}\text { Anti-nuclear } \\
\text { antibodies }\end{array}$}} & \multirow{3}{*}{$\begin{array}{l}\text { Anti-DNA } \\
\text { antibodies }\end{array}$} & \multirow{3}{*}{$\begin{array}{l}\begin{array}{l}\text { Circulating } \\
\text { immune } \\
\text { complexes }\end{array} \\
\text { SDU }\end{array}$} & \multirow{2}{*}{\multicolumn{3}{|c|}{$\begin{array}{l}\text { Immunoglobulins } \\
(\mathrm{g} / \mathrm{l})\end{array}$}} \\
\hline & & & & & & & & & & \\
\hline & & & $\lg G$ & $\lg M$ & Type & & & $\lg M$ & & $\operatorname{Ig} A$ \\
\hline AS & 58 & $<32$ & 640 & 80 & $\mathbf{H}(\mathbf{P})^{*}$ & 10 & 10 & $4 \cdot 1$ & & $4 \cdot 3$ \\
\hline BS & 67 & 128 & 160 & 80 & $\mathrm{P}(\mathrm{S})$ & Neg & 6 & $2 \cdot 2$ & & $1 \cdot 3$ \\
\hline
\end{tabular}

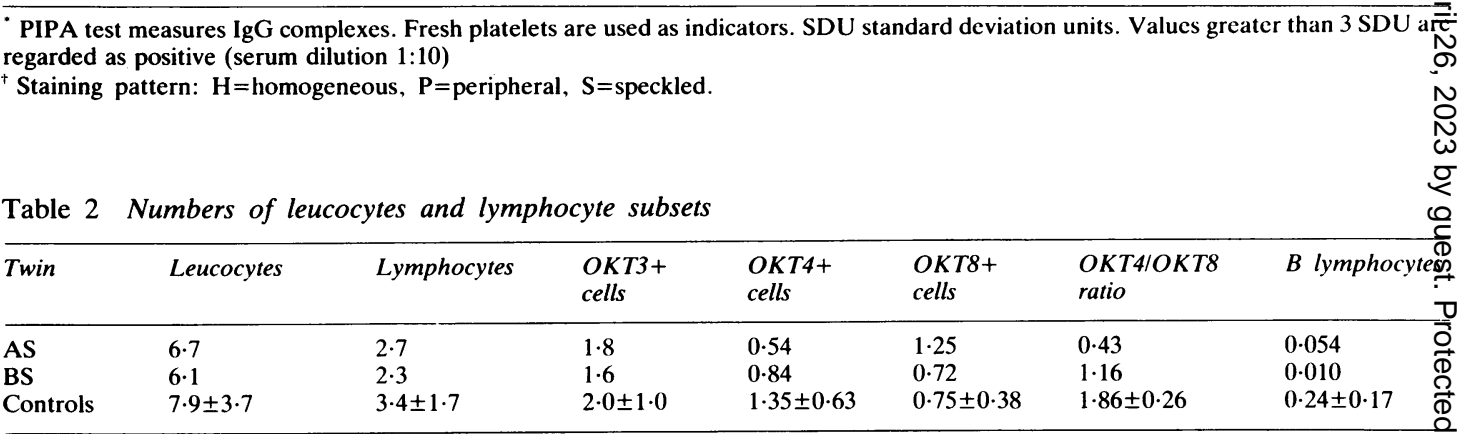

The number of cells is expressed as $\times 10^{-9} / 1$. The controls provide a normal range for the number of different cells population 
Table 3 Lymphocyte capacity for blastogenesis and immunoglobulin secretion

\begin{tabular}{|c|c|c|c|c|c|c|c|c|}
\hline & \multicolumn{8}{|c|}{ Lymphocyte blastogenesis (cpm) } \\
\hline & \multicolumn{4}{|c|}{ PHA $125 \mu \mathrm{g} / \mathrm{ml}$} & \multicolumn{4}{|c|}{ Con A $25 \mu \mathrm{g} / \mathrm{ml}$} \\
\hline & \multicolumn{2}{|c|}{ Whole blood } & \multicolumn{2}{|c|}{ lsolated lymphocytes } & \multicolumn{2}{|c|}{ Whole blood } & \multicolumn{2}{|c|}{ Isolated lymphocytes } \\
\hline & \multicolumn{2}{|c|}{ Native per $10^{+} T$-cells } & \multicolumn{2}{|c|}{ Native per $10^{+} T$-cells } & \multicolumn{2}{|c|}{ Native per $10^{+} T$-cells } & \multicolumn{2}{|c|}{ Native per $10^{5} \mathrm{~T}$-cells } \\
\hline AS & 63075 & 14079 & 34144 & 20693 & 29376 & 6557 & 10307 & 6244 \\
\hline BS & 60694 & 16125 & 31538 & 18022 & 30718 & 7777 & 4128 & 2359 \\
\hline \multirow[t]{4}{*}{ Controls } & $\begin{array}{l}67158 \pm \\
139(2)\end{array}$ & $\begin{array}{c}16883 \pm \\
9864\end{array}$ & $\begin{array}{c}46939 \pm \\
9614\end{array}$ & $\begin{array}{c}30589 \pm \\
6859\end{array}$ & $\begin{array}{l}32648 \pm \\
14446\end{array}$ & $\begin{array}{l}8336 \pm \\
4651\end{array}$ & $\begin{array}{c}30589 \pm \\
6859\end{array}$ & $\begin{array}{c}21204 \pm \\
6136\end{array}$ \\
\hline & \multicolumn{8}{|c|}{ Immunoglobulin production } \\
\hline & \multicolumn{3}{|c|}{ Spontaneous PFC } & \multicolumn{5}{|c|}{ Polyvalent PFC in cultures stimulated by } \\
\hline & $\lg G$ & $\lg M$ & $\lg A$ & $R P M I$ & $P W M$ & $P W M+H C$ & \multicolumn{2}{|l|}{$P W M+\operatorname{con} A$} \\
\hline AS & 180 & 300 & 640 & $17(0)$ & 1800 & $74(0)$ & $(94)^{5}$ & \\
\hline BS & 60 & 200 & 640 & 2200 & 10800 & 15600 & $3400 \quad(70)$ & \\
\hline Controls & $76 \pm$ & $58 \pm$ & $264 \pm$ & $1721 \pm$ & $17129 \pm$ & $28803 \pm$ & $5671 \pm(70 \pm$ & \\
\hline & 110 & 69 & 465 & 1498 & 15660 & 19188 & $8630) \quad 22)$ & \\
\hline
\end{tabular}

Mean counts per minute $(\mathrm{cpm}) \pm \mathrm{SD}$ are given. The controls provide a normal range for the assays.

$\mathrm{PFC}=$ plaque forming cells.

Suppression percentage is given in parentheses.

the optimal concentrations of PHA and con A are presented in Table 3 . The augmentation indices obtained in lymphocyte cultures with Ind, Cim, and $\mathrm{Pen}+\mathrm{Cu}$ from patients and controls were of the same magnitude (data not shown).

The number of $\mathrm{B}$ cells secreting spontaneously IgA and IgM was increased in the twins. In the PWM-driven system the SLE patient (AS) showed a reduced PFC capacity. In the presence of hydrocortisone the PFC capacity of diseased sibling showed a four fold increase, while the increase in the healthy sibling and in controls was below 2. Con A induced suppression of PFC was similar in both the twins and the controls (Table 3).

\section{Discussion}

The twin with SLE (AS) had a reversed OKT/4 OKT8 ratio. This finding is in accordance with previous data in SLE, in which it has been associated with a reduction of OKT4+ cells. ${ }^{20} 21$ The number of OKT4+ lymphocytes was reduced in our patient, but in addition an increase of OKT8+ cells was recorded. The healthy sibling (BS) had lowered OKT4/OKT8 ratio due to a decreased number of OKT4+ cells. Serologically inactive patients have previously shown no abnormalities in this respect. ${ }^{21}$

Indomethacin and cimetidine sensitive suppressor cells and copper sulphate plus D-penicillamine sensitive helper cells were normal in the twins. In the PFC assay the activity of con A sensitive suppressor cells was observed to be normal or slightly increased. This is in accordance with a previous report, 22 although suppressor cells have also been shown to be defective in $\operatorname{SLE}^{3.3}$ and the defect has been considered a genetic marker for SLE. ${ }^{3}$ The abnormality in con $\mathrm{A}$ responses cannot be explained via suppressor cells.

Endogenous polyclonal B cell activation together with defective $B$ cell function and regulation has been linked to SLE.$^{3-7}$ We found slightly enhanced spontaneous and decreased PWM induced PFC capacity in both twins: the abnormalities were more pronounced in the diseased sibling (AS) in concordance with previous studies. 56 The former finding may reflect endogenous $B$ cell activation and the latter defective helper T cell activity. ${ }^{5+}$ The latter is also supported by the decreased number of OKT4+ cells in both twins (Table 2). Furthermore overactive hydrocortisone sensitive suppressor cells were demonstrated in the diseased sibling (AS) (Table 3).

Our twins have close similarities with the HLAidentical male twins discordant for lupus described very recently by Schroeder et al. ${ }^{25}$ These include circulating autoantibodies. B cell function with and without PWM stimulation, and some enhanced suppressor cell activity. However. Schroeder and colleagues did not determine $\mathrm{T}$ cell subpopulations and reported exuberant $T$ cell function, which was not recorded in the present investigation. 
Previously, decreased $\mathrm{T}$ lymphocyte responses have been associated with HLA-B8 and B8 and Dr3 antigens, ${ }^{26} 27$ as a reflection of the action of genes predisposing to autoimmunity. In this study HLAB8 and Dr3 antigens could be associated only with a decrease of helper $T$ cell number and decreased con A responses.

The genetic factors may be associated with different immunological and clinical features of SLE. ${ }^{9-11}$ The finding of more concordance of SLE in monozygotic than dizygotic twins provides evidence for genetic factors, whereas a documented discordance in monozygotic twins supports the importance of environmental factors. ${ }^{128}$ In twins concordant for SLE the outbreak of the disease has occurred within five years (in one pair after an interval of 16 years). The follow-up period of twins discordant for disease has been only up to five years. ${ }^{1}$ Although our twins were monozygotic, the healthy one (BS) had been symptomless over 20 years after the outbreak of the disease in the other. Steinberg et al. ${ }^{29}$ reported HLA-A,B,Dr genotyping in three families with SLE, and the affected persons did not share HLA haplotypes. Furthermore, it has been proposed that genetic factors predispose to autoimmunity via immunoregulatory circuits before autoantibodies or clinical symptoms appear. ${ }^{3811}$ Both of the twins studied have autoantibodies; but the OKT4/OKT8 ratio as well defective PWM induced plasma cell differentiation were abnormal only in the SLE patient. The observations are not in accordance with the successive events resulting in autoimmunity: genetic factors - defect in immunoregulatory circuits - formation of autoantibodies - clinical symptoms. ${ }^{3}$ Our findings show that SLE susceptibility is not dependent on chromosome 6 (HLA region), as shown also in previous studies. ${ }^{11} 252829$

In the present study we describe female monozygotic twins discordant for over 20 years for SLE. Thus genetic factors (e.g., HLA B8, Dr3) are unlikely to be crucial in predisposing to the disease. In addition the extensive immunological analysis does not either support the notion of an inherited deficiency in immune functions ${ }^{28}$; the aberrations observed are most probably secondary to the disease process. We suggest that environmental and/or endogenous factor(s) as well as genetic or immunological operate in predisposition to and expression of the illness.

\section{References}

1 Block S R, Winfield J B, Lockshin M D, D'Angelo W A, Christian C L. Studies of twins with systemic lupus erythematosus. A review of the literature and presentation of 12 additional sets. Am J Med 1975; 59: 533-52.
2 Arnett F C. Shulman L E. Studies in familial systemic lupus erythematosus. Medicine (Baltimore) 1976; 55: 313-22. =

3 Talal N. Systemic lupus erythematosus, autoimmunity, sex ans inheritance. $N$ Engl J Med 1979; 301: 838-9.

4 Miller K B, Schwartz R S. Familial abnormalities of suppresso cell function in systemic lupus erythematosus. $N$ Engl $J$ Me 1979; 301: 803-9.

5 Ginsburg W W, Finkelman F D, Lipsky P E. Circulating an pokeweed mitogen induced immunoglobulin secreting cells i® systemic lupus erythematosus. Clin Exp Immunol 1979; 35: 76-88.

6 Tan P, Pang G. Wilson J D. Immunoglobulin production in vitro by peripheral blood lymphocytes in systemic lupuङ erythematosus: helper $\mathrm{T}$ cell defect and B cell hyperreactivity Clin Exp Immunol 1981; 44: 548-54.

7 Takeuchi T, Abe T, Kiyotaki M, et al. In vitro immune response of SLE lymphocytes. The mechanism involved in 1 cell activation. Scand J Immunol 1982; 16: 369-77.

8 Morrow W J W, Youinou P, Isenberg D A. Snaith M LA Systemic lupus erythematosus: 25 years of treatment related to immunopathology. Lancet 1983; i: 206-10.

9 Schur P H. Meyer I, Garovoy M, Carpenter C B. Association between systemic lupus erythematosus and the major histocome patibility complex: clinical and immunological considerations Clin Immunol Immunopathol 1982; 24: 263-75.

10 Hughes G R V, Batchelor J R. Genetics of systemic lupus erythematosus. $\mathrm{Br}$ Med $J$ 1983; 286: 416-7.

11 Lippman S M. Arnett F C, Conley C L. Ness P M. Meyers D A Bias W B. Genetic factors predisposing to autoimmun diseases. Autoimmune hemolytic anemia. chronic trombocye topenic purpura, and systemic lupus erythematosus. $A m J$ Me $\$$ 1982; 73: $827-40$

12 Cohen A S. Reynolds W E. Franklin E C, Kulka J P, Rope $\mathrm{M} \mathrm{W}$, Wallace S L. Preliminary criteria for classification of systemic lupus erythematosus. Bull Rheum Dis 1971: 21: 643-8D

13 Kung P C. Goldstein G, Reinherz E L, Schlossman S F Monoclonal antibodies defining distinctive human T cell surfac $\overrightarrow{\bar{O}}$ antigens. Science 1979; 206: 347-9.

14 Soppi A-M, Soppi E, Eskola J, Jansén C T. Cell-mediateđ immunity in Darier's disease: effect of systemic retinoif therapy. Br J Dermatol 1982; 106: 141-52.

15 Lipsky P E, Ziff M. The effect of D-penicillamine on mitoge華 induced human lymphocyte proliferation: synergistic inhibition by D-penicillamine and copper salts. J Immunol 1978; 120? 1006-13.

16 Goodwin J S, Webb D R. Regulation of the immune respons by prostaglandins. Clin Immunol Immunopathol 1980; 15 $106-16$.

17 Gifford R R M. Hatficld S M. Schmidtke J R. CimctidinS induced augmentation of human lymphocyte blastogenesis by mitogen, bacterial antigen. and alloantigen. Transplantatio 1980; 29: $143-8$.

18 Fauci A S, Whalen G, Burch C. Activation of human BO lymphocytes. XVI. Cellular requirements, interactions, and immunoregulation of pokeweed mitogen induced total immunoglobulin producing plaque-forming cells in peripheran blood. Cell Immunol 1980; 54: 230-40.

19 Bialasiewicz A A, Lubach D, Marghescu S. Immunologica features of psoriasis. Effects of Ro 10-9359, concanavalin Ao pokeweed mitogen and methotrexate on cultivated lymphof cytes. Arch Dermatol Res 1981; 271: 29-40.

20 Smolen J S, Chused T M, Leiserson W M, Reeves J P, Alling D, Steinberg A D. Heterogeneity of immunoregulatory T celt subsets in systemic lupus erythematosus. Am J Med 1982; 72웅 783-90.

21 Bakke A C, Kirkland P A, Kitridou R C, et al. T Lymphocyte्ष subsets in systemic lupus erythematosus. Arthritis Rheum 1983을 26: $745-50$.

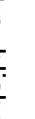
. 
22 Neis K M, Stewens R H, Louie J S. Normal T cell regulation of IgG synthesis in systemic lupus erythematosus. J Clin Lab Immunol 1980; 4: 69-75.

23 Ilfeld D N, Krakauer R S. Suppression of immunoglobulin synthesis of systemic lupus erythematosus patients by concanavalin A activated normal human spleen cell supernatants. Clin Immunol Immunopathol 1980; 17: 196-202.

24 Kamagui S, Sredni B, House S, Steinberg A D, Green I. Defective regulation of $B$ lymphocyte colony formation in patients with systemic lupus erythematosus. J Immunol 1982; 128: $258-62$.

25 Schroeder J L. Hahn B H, Beale M G. Pletscher L S. Genetic, hormonal, and immune studics in a pair of identical twin boys discordant for lupus. Arthritis Rheum 1982; 26: 1399-404.
26 Kallenberg C G M, van der Voort-Beclen J M, D'Amaro J, The $\mathrm{T} \mathrm{H}$. Increased frequency of B $8 / \mathrm{Dr} 3$ in scleroderma and association of haplotype with impaired cellular immunc response. Clin Exp Immunol 1981: 43: 478-85.

27 McCombs C C. Michalski J P. Lymphocytc abnormality associated with HLA-B8 in healthy young adults. $J$ Exp Med 1982: 156: 936-41.

28 Block S R, Lockshin M D, Winficld J B, et al. Immunologic observations on 9 sets of twins cither concordant or discordant for SLE. Arthritis Rheum 1976: 19: 545-54.

29 Steinberg A D. Reinertsen J L. Plotz P H, Balow J E. Klippel J H. Immunologic aspects. Systemic lupus erythematosus: cvolving concepts (Decker J L. moderator). Ann Intern Med 1979; 91: 587-604. 